\title{
Unheard Voices - sorgramte danske elevers oplevelser og perspektiver på den stotte de modtog da de vendte tilbage til skolen
}

(ph.d.-forsvar: december 2015)

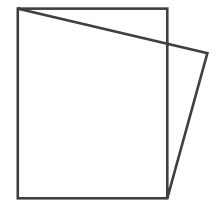

Martin Lytje, Faculty

of Education,

University of

Cambridge/Kræftens

Bekæmpelse

\section{Baggrund og forskningsdesign}

I Danmark mister omkring 1700 børn

hvert år en forælder (“OmSorg," 2016).

International litteratur (Cerel, Fristad,

Verducci, Weller, \& Weller, 2006; Melhem, Moritz, Walker, Shear, \& Brent, 2007) har påvist, hvordan tab af en forælder i dag betragtes som en af de mest traumatiske oplevelser, der kan overgå et barn. Få undersøgelser har spurgt de sorgramte børn om deres oplevelser af mødet med skolen, når de vender tilbage efter tabet af en forælder. Dette skyldes sandsynligvis en eksisterende samfundsmæssig forestilling om, at det er for svært for sorgramte børn at fortælle om sådanne oplevelser.

Min ph.d.-afhandling med titlen Unheard Voices: Parentally Bereaved Danish Students' Experiences and Perceptions of the Support Received Following the Return to School (Lytje, 2016) havde til formal at udfordre holdningen om, at børn ikke kan tale om tabet af en forælder. Derudover ønskede jeg at give børnene mulighed for at fortælle deres historier. Studiet undersøgte, hvordan 39 elever i alderen 9-17 år oplevede det at vende tilbage til skole efter en forælders dødsfald. Det forsøgte endvidere at agere talerør for de idéer og holdninger de sorgramte elever havde i forhold til, hvad der er godt sorgarbejde, og hvilke behov de havde i denne svære situation. For at sikre eleverne tilgængelig støtte efter interviewene var færdiggjort blev deltagerne rekrutteret fra fem danske sorggrupper, hvor syv fokusgrupper blev afholdt. Selve datagenereringen var opdelt i to faser. I Fase I, der varede et år, besøgte jeg fire sorggrupper fire gange. Her diskuterede eleverne temaer som at vende tilbage til skolen og ønsker til støtte. Fase II, blev oprettet som følge af de data, der blev genereret i den foregående fase. Datagenereringen involverede her et besøg i tre sorggrupper $\mathrm{i}$ Sydjylland og på Fyn. Disse interviews havde fokus på at undersøge, om børn i forskellige regioner af Danmark havde samme holdninger til centrale spørgsmål om sorgarbejde. 
Tema: Innovation og uddannelse

\begin{abstract}
Afhandlingens hovedpointer: Fase I
Der blev foretaget en tematisk analyse af de indsamlede data baseret på en tilpasset version af Braun og Clarkes (2006) rammeværk for metoden. Denne analysemetode blev valgt, da jeg ønskede at lade børnenes ord tale så meget for sig selv som muligt. Analysen ledte til genereringen af 11 temaer, der dækkede oplevelser af at vende tilbage til skolen og ønsker til hjælp. Det følgende afsnit vil fokusere på fire af studiets fund.
\end{abstract}

\section{Elever vil ses som samarbejdspartnere} Jeg tœnker sådan lidt, at lœrerne måske skulle prøve at se på det omvendt. At man måske nœrmest bliver mere ked af det hvis de ikke spørger, hvordan vil du gerne have hjœlp. (Lisa, 15)

Majoriteten af eleverne fremhævede, at de selv havde en unik indsigt i egne behov. Det kunne derfor være svært at vende tilbage til en skole, hvor de enten ikke blev inddraget, eller hvor de skulle deltage i en masse aktiviteter, selvom de ikke havde lyst. Eleverne ville gerne inkluderes i skolens planlægningsproces og ønskede i højere grad at blive set som samarbejdspartnere, når lærerne implementerer støttemekanismer i deres liv. Dette skete dog sjældent.

\section{Faste rammer giver tryghed}

Det der med at kunne komme uden for og få en pause, det vil jeg tro, kunne hjœlpe mig rigtigt meget. Ud og ligesom at blive glad, i stedet for at sidde inde i klassen og vœre ked af det og alle kigger på en. (Lykke, 12)

Interviewene fastlagde, at perioden, der efterfulgte et dødsfald, ofte kan være meget kaotisk. Det var derfor vigtigt for den sorgramte at have faste strukturer at støtte sig op af. At sidde i klasseværelset og være ked af det, men samtidig være i tvivl om hvorvidt man måtte forlade lokalet, var en ekstra byrde, børnene ikke havde brug for. I de fleste tilfælde prøvede skolerne at opstille sådanne rammer i takt med, at lærerne blev opmærksomme på udfordringerne. Det kunne være rammer, såsom at man måtte gå uden for klassen, hvis man blev ked af det, og eventuelt tage en ven med. De fleste elever ønskede dog, at sådanne regler var til stede fra dag et. På den måde var støtten tilgængelig, når eleven havde brug for den, frem for først at være tilgængelig efter at eleven havde haft brug for den.

\section{Mindehøjtideligheder og \\ gaver er problematiske}

På min skole der fik jeg et kort fra afdelingslederen. Det var et meget fint kort, hun havde skrevet, hvor hele min klasse havde skrevet under. Men min halvsøster $i$ en anden klasse fik det samme kort, hvor der stod de samme ting bare med hendes klasses navne. Så bliver det bare sådan lidt upersonligt. De havde også købt et hårbånd. Det var bare sådan lidt mcerkeligt. (Siv, 15)

Flere elever oplevede, at skolerne holdt mindehøjtideligheder og gav dem en gave i tiden efter dødsfaldet. Mindehøjtideligheder kunne være alt fra, at skolen samledes og hejste flaget på halvt, til at man i klassen tændte et lys. Gaver kunne være en bog med tegninger, personlige beskeder fra klassekammeraterne, lysestager og meget andet. Især de ældre elever var generelt meget skeptiske over for begge tiltag. De følte, at sådanne ritualer kunne være med til sætte uønsket fokus på deres situation i en tid, der allerede var meget kaotisk. Dette i en periode, hvor de vendte tilbage til skolen i håbet om at finde stabilitet og ro. Personlige gaver, såsom breve fra klassekammeraterne, blev modtaget mere positivt. Disse formåede at vise eleven, at skolen forstod, at de gik igennem en svær tid og gerne ville støtte dem.

Skolerne glemmer den langsigtede sorg Man kommer jo til at mangle personen resten af livet. Hvorfor skal man så kun vœre ked af det i en kort periode af livet? Jeg er stadigvœk ked af det og tœnker på personen. Det kan godt vœre, at man har det godt og tœnker på det på en god måde i en periode, og så kan man vœre ked af det senere hen. Det er meget forskelligt. (Siv, 15)

Der var en generel oplevelse blandt eleverne af, at lærere og kammerater ofte blev dårligere til at støtte dem, som tiden gik. Dette kunne få deltagerne til at føle sig meget alene i verden. Selvom de havde både gode og dårlige dage, såvel som tidspunkter hvor de ikke tænkte på deres tab, så var sorgen en konstant følgesvend. Samtidig kunne ubehagelige situationer opstå, hvis klassen havde temaer om døden, men ikke forinden havde forberedt den sorgramte elev på dette. Ligeledes stillede en af pigerne spørgsmålstegn til, hvorfor hendes lærer kunne huske, at en elev havde nøddeallergi, men konstant glemte at hun havde mistet sin far.

Afhandlingens hovedpointer: Fase 2 I anden del af afhandlingen præsenteredes modellen for social navigation af sorg i ungdommen (MNU). Denne har til formål at visualisere de udfordringer, unge mennesker møder, når de arbejder med deres sorg. Her er det en stor udfordring at navigere imellem egne 
behov overfor kulturelle forventninger fra lokalmiljøet, familien og samfundet. Modellen blev skabt på baggrund af de centrale temaer, der blev opdaget i løbet af studiets fase I. Temaerne synes at have direkte indvirkning på, hvordan deltagerne navigerede igennem deres sorg og er derfor blevet omformet til faktorer i MNU-modellen. Ordet "ungdom" bliver brugt, fordi studiet ikke fandt nogen indikationer på at yngre børn (0-9 år) besidder den nødvendige kapacitet til at forstå de sociale konventioner, som influerer, hvordan modellen fungerer. De tre faktorer, der påvirker den unges valg, er: At vœre anderledes, At have kontrol og At vœre i sorg. Måden, hvorpå samfundet tager imod den unge, og konflikter bliver løst, former, hvordan eleven navigerer igennem sin hverdag. Forsøger vedkommende, som eksempel, at fortælle sine venner om sin sorg, men bliver drillet om tabet, er der stor sandsynlighed for, at eleven fremover lader være med at tale om emnet. De tre faktorer vil kort blive præsenteret i det følgende:

At være anderledes: Relationer fra nærmiljøet har ofte svært ved at tale med eleven om dennes sorg. Dette gælder både venner, klassekammerater, lærere og andre voksne. En sådan akavethed kan hurtigt få den sorgramte unge til at føle sig anderledes og isoleret. Baseret på viden fra dette studie måtte eleverne ofte vælge mellem to strategier i forhold til det overstående dilemma. 1) At tale med klassen om deres oplevelser og risikere, at de blev ubekvemme over emnet; eller 2) At lade som om intet var sket. Størstedelen af deltagerne valgte at lade som ingenting og prøvede at genfinde deres gamle plads i klassen. De, der gik den modsatte vej og delte deres oplevelser, følte sig ofte anderledes, og at deres venner blev utrygge, når de talte om deres sorg eller helt forsøgte at undgå dem.

At være i kontrol: Når unge oplever tabet af en forælder, kan det være svært at fastholde følelsen af at have kontrol over eget liv. Hvis man ikke kan forhindre en nærtstående i at dø, hvad kan man så? Det er vigtigt, at den sorgramte efter dødsfaldet genvinder følelsen af at have kontrol og medbestemmelse over sit eget liv. Faktoren "at være i kontrol" relaterer sig derfor til ønsket om at genvinde styringen og kunne vende tilbage til en "normal" hverdag. Selvom dette er en svær opgave, forsøger den unge ofte at genskabe en følelse af kontrol ved at kontrollere alt, hvad vedkommende kan, såsom hvem der ved hvad om dødsfaldet. Ligeledes eksisterer der ofte et ønske om at blive inkluderet i beslutningsprocesserne, der relaterer sig til, hvordan skolen håndterer elevens sorg.

At være i sorg: Sorg er både en konstant følelse og samtidig noget, der kan udløses af særlige oplevelser. Den er altid til stede som en fornemmelse af tristhed og i form af påtrængende tanker om tabet og det tabte forhold. Den sorgramte kan i visse tilfælde tage pauser fra sorgen, men tankerne vender altid tilbage. Sorgen kan ligeledes udløses af visse begivenheder, som for eksempel: fødselsdage, temadage med emner relaterede til sorg og begivenheder såsom skolekoncerter og ferier. Tankerne, der følger med sorgen, kan gøre det svært for eleven at tænke på andet end den afdøde og endvidere lede til tab af koncentration og emotionelle reaktioner. De tre faktorer influeres af det miljø, den unge er i og de oplevelser, vedkommende har. Dette kan føre til, at nogle beslutnin- ger bliver taget, som kunne være anderledes, hvis andre faktorer havde været vigtigere i øjeblikket. Ofte er teenagere gode til at lytte til egne behov. Problemerne opstår, når disse behov kommer i konflikt med de forventninger, der er til den sorgramte elev fra venner, lærer og samfund. Kan læreren hjælpe eleven med at håndtere de nævnte problematikker, kan vedkommende gøre både det at vende tilbage til skolen og sorgprocessen nemmere for eleven. Sorgen vil altid være der, men det behøver følgekonflikterne ikke. For en fuld beskrivelse af MNU-modellen henvises til den originale afhandling (Lytje, 2016).

Der har i et historisk psykologisk perspektiv ofte været fokus på at se sorg som en primær internaliseret og individuel proces. Et af denne afhandlings vigtigste budskaber er, at professionelle bør have styrket fokus på at se sorg som en social proces. De følgekonsekvenser, der kan være, når den unges behov kolliderer med samfundets forventninger, kan i høj grad påvirke individet og på mange måder give lige så store udfordringer som sorgen selv. Håbet er, at MNU-modellen kan være med til at skabe en bedre forståelse for denne problematik.

Derudover konkluderer afhandlingen, at der er behov for, at lærere i højere grad ser børn som kompetente samarbejdspartnere og eksperter på egne behov. Det er en misforstået venlighed, når vi skjuler ting eller tager beslutninger på børns vegne i et forsøg på at skærme dem. Ikke at være inkluderet og ikke vide, hvad der foregår, skaber uro hos den sorgramte elev og en følelse af mangel på kontrol over eget liv. Ved i stedet at fokusere på en ligeværdig samarbejdsproces undgås mange af de problematikker, der blev belyst i denne afhandling. 
Tema: Innovation og uddannelse

Kan man styrke tilliden og magtbalancen mellem lærer og elev ved at udbygge deres forhold til en respektfuld samarbejdsproces, bliver det også nemmere for barnet selv at rejse problematikker. Desuden viste projektet med al tydelighed, at vi som professionelle kan lære utroligt meget af at lytte til de målgrupper, vi ønsker at hjælpe. Ligeledes, at de børn og unge, der blev interviewet, var yderst kompetente i at deltage i debatten omkring, hvordan deres sorg skal håndteres.

\section{REFERENCER}

Braun, V., \& Clarke, V. (2006). Using thematic analysis in psychology. Qualitative Research in Psychology, 3(2), 77-101. http://doi.org/10.1191/1478088706qp063oa

Cerel, J., Fristad, M. A., Verducci, J., Weller, R. A., \& Weller, E. B. (2006). Childhood Bereavement: Psychopathology in the 2 Years Postparental Death. Journal of the American Academy of Child \& Adolescent Psychiatry, 45(6), 681-690. http://doi. org/10.1097/01.chi.0000215327.58799.05

Lytje, M. (2016). Unheard Voices: Parentally Bereaved Danish Students' Experiences and Perceptions of the Support Received Following the Return to School. (PhD afhandling). University of Cambridge. Cambridge.

Melhem, N. M., Moritz, G., Walker, M., Shear, M. K., \& Brent, D. (2007). Phenomenology and Correlates of Complicated Grief in Children and Adolescents. Journal of the American Academy of Child \& Adolescent Psychiatry, 46(4), 493-499. http://doi. org/10.1097/chi.Ob013e31803062a9

OmSorg. (2016). Set 10. februar, 2016, from www.cancer.dk/omsorg/omsorg.htm 